\title{
OVERVIEW OF GESTATIONAL DIABETES MELLITUS AND ITS EFFECT ON MATERNAL, FOETAL AND NEONATAL OUTCOME
}

\author{
Gauri Raghunath Shinde1, Manisha Laddad², Digvijay Kadam ${ }^{3}$
}

${ }_{1}^{1}$ Assistant Professor, Department of Obstetrics and Gynaecology, Krishna Institute of Medical Sciences, Deemed University, Karad, Maharashtra, India.

${ }^{2}$ Associate Professor, Department of Obstetrics and Gynaecology, Krishna Institute of Medical Sciences, Deemed University, Karad, Maharashtra, India.

${ }^{3}$ Senior Resident, Department of Obstetrics and Gynaecology, Krishna Institute of Medical Sciences, Deemed University, Karad, Maharashtra, India.

\begin{abstract}
BACKGROUND
ABSTRACT

The incidence varies considerably from 1 - 14\%, depending upon ethnicity, selection criteria and diagnostic tests performed. GDM affects the index pregnancy as well as two generations, mother and her child. Short-term intensive care in pregnancy, early detection and timely management will improve the good pregnancy outcome.

The objectives of the present study are 1. to evaluate incidence of GDM in present tertiary care centre, Southern Maharashtra population 2. to evaluate maternal, foetal and neonatal complications; and 3. to evaluate risk factors for GDM.
\end{abstract}

\section{MATERIALS AND METHODS}

The present prospective study was conducted in OBG Department, KIMSDU, Karad from January 2017 to May 2018. A total of 3960 booked patients delivered in Krishna Hospital from January 2017 to May 2018. All these included patients in the present study underwent OGTT around $24-28$ weeks of gestation. Those whose glucose levels were normal again underwent repeat OGTT at around $32-34$ wks. Those with at least two readings abnormal from OGTT were considered as GDM patients. 120 patients were diagnosed as GDM, 20 were lost for follow-up. 100 patients were considered in the study. These patients were observed throughout the pregnancy, delivery and 6 weeks postpartum for development of maternal, and foetal and neonatal complications related to GDM and data collected for maternal foetal complications (antenatal, intrapartum, postpartum), gestational age at detection of GDM, delivery, mode of delivery and need for NICU etc.

\section{RESULTS}

Incidence of GDM in Krishna Hospital was 3\%. In the present study, incidence of GDM in 25 - 30 yrs. old women was $70 \%$. In present study, $28 \%$ patients had positive family and past history. In the present study, GDM was detected in $64 \%$ multigravida. It indicates increasing parity as a risk factor for developing GDM. 74\% patients delivered after 37 weeks of gestation and $20 \%$ had preterm deliveries. $6 \%$ patients aborted before 24 weeks of gestation, $36 \%$ underwent elective LSCS and $16 \%$ of the patients underwent emergency LSCS. In the present study 6 patients had abortion, 20 had preterm labour ( 24 weeks to 36 weeks) and 10 patients had PPROM. 10 patients had polyhydramnios, out of these, one required therapeutic amniotic fluid tapping (as amniotic fluid index was 32 at gestational age of 28 weeks and due to maternal discomfort), 18 patients had recurrent UTI, vaginal candidiasis or both which was treated conservatively. 16 patients had PIH, out of which 10 were on medications- Tb. Nifedipine $10 \mathrm{mg}$ or $\mathrm{Tb}$. Labetalol $100 \mathrm{mg}$ or combination of these drugs according to severity. Out of $100 \mathrm{GDM}$ patients, 4 patients were known or diagnosed with hypothyroidism during present pregnancy. LBW babies $<2.5 \mathrm{~kg}$ was $8.4 \%$ in the present study. In the present study, 50.5\% live babies required NICU admissions. Out of 100 women, 66 women followed up till 6 weeks post-partum. Out of these, 10 were diagnosed with glucose intolerance on GTT and 3 as DM.

\section{CONCLUSION}

Preventive measures for type 2 diabetes should start before birth and should be continued lifelong in children born to GDM mothers. To achieve this, what is needed is a small screening test for GDM in antenatal period, timely diagnosis and good glycaemic control. These preventive measures decrease neonatal morbidity and mortality and chances of developing diabetes in these children in their life. This will reduce the financial and social burden of managing complications of untreated diabetes.

\section{KEY WORDS}

GDM, Diabetes, Maternal Complications in GDM, Foetal and Neonatal Complications in GDM.

HOW TO CITE THIS ARTICLE: Shinde GR, Laddad M, Kadam D. Overview of gestational diabetes mellitus and its effect on maternal, foetal and neonatal outcome. J. Evolution Med. Dent. Sci. 2018;7(35):3900-3905, DOI: 10.14260/jemds/2018/872

'Financial or Other Competing Interest': None.

Submission 17-07-2018, Peer Review 10-08-2018,

Acceptance 16-08-2018, Published 27-08-2018.

Corresponding Author:

Dr. Gauri Raghunath Shinde,

C/s. No. 1549, Opposite Swimming Tank,

Ganesh Nagar, Sangli-416416, Maharashtra, India.

E-mail:drgauri8@gmail.com

DOI: $10.14260 /$ jemds $/ 2018 / 872$

\section{(c) $(\rightarrow)$}

\section{BACKGROUND}

Diabetes mellitus is one of the commonest medical problems encountered, both during the pregnancy and out of it. In this disease almost more than any other disease, "coming events cast their shadow before." The incidence varies considerably, from 1 - 14\%, depending upon ethnicity, selection, criteria and diagnostic tests performed. ${ }^{1}$ Indian women have high prevalence of diabetes and their relative risk of developing GDM is 11.3 times compared to white women. ${ }^{2}$ In pregnancy 
significant changes occur in maternal carbohydrate metabolism and high level of placental hormones (human chorionic somatomammotropin, oestrogen, progesterone, prolactin and cortisol) are implicated in developing insulin resistance. This increases compensatory increased insulin secretion, when this compensation lost the GDM (Gestational Diabetes Mellitus) occurs. GDM affects the index pregnancy as well as two generations, mother and her child. GDM associated with maternal as well as foetal and neonatal affection and increased chances of maternal and early childhood Diabetes Mellitus, childhood obesity etc. complications. GDM will also affect the social and economic burden of untreated diabetes. So short-term intensive care in pregnancy, early detection and timely management will improve the good pregnancy outcome.

\section{Aims and Objectives}

1. To evaluate incidence of GDM in present tertiary care centre, Southern Maharashtra population.

2. To evaluate maternal, foetal and neonatal complications.

3. To evaluate risk factors for GDM.

\section{MATERIALS AND METHODS}

This prospective observational study was conducted in OBGY Department, KIMSDU, Karad. It was a prospective study and data collection was done from January 2017 to May 2018. Patients included in this study were booked patients who came for routine ANC care in OBGY OPD and delivered in OBGY Department, KIMSDU, Karad. Total 3960 booked patients delivered in Krishna Hospital from January 2017 to May 2018. All these included patients in present study underwent OGTT around $24-28$ weeks of gestation. Those whose glucose levels were normal again underwent repeat OGTT at around $32-34$ weeks. After 100 gms, OGTT fasting $>95 \mathrm{mg} / \mathrm{dL}, 1 \mathrm{hr}$. > $180 \mathrm{mg} / \mathrm{dL}, 2 \mathrm{hrs} .>155 \mathrm{mg} / \mathrm{dL}, 3 \mathrm{hrs}$. $>140 \mathrm{mg} / \mathrm{dL}$, any of these two values was abnormal then patient was considered as GDM (Carpenter and Coustan, ACOG 2001 criteria for diagnosis of GDM).3,4

120 patients were diagnosed as GDM, 20 were lost for follow-up. 100 patients were considered in the study. A detailed clinical history, high risk factors for GDM (previous macrosomic baby, family history of DM/ GDM, GDM in previous pregnancy, bad obstetric history, anomalies in previous baby, polyhydramnios etc.). A through clinical examination was performed for all these patients. They underwent all routine investigations like complete blood count, blood grouping and typing, HIV, HBsAg and urine routine microscopy. Specific investigations such as HbA1c, Liver function test, Renal function test, Fundoscopy, USG to rule out foetal anomaly around 18 weeks and repeat USG accordingly for foetal growth and to diagnose Macrosomia/ IUGR throughout as pregnancy progresses. All GDM patients were closely observed for development of complications related to GDM such as Polyhydramnios, Macrosomia, PIH, IUGR, recurrent UTI, vaginal candidiasis, preterm labour, PPROM and treated accordingly. All patients diagnosed as GDM were advised diabetic diet and glucose levels were monitored with FBS and PLBS after 2 weeks. Those who were controlled on this continued with diet plan. But those who were not controlled on diet shifted to insulin and diet therapy and monitored accordingly. All these women followed up till term and after delivery till 6 weeks. Data was collected for maternal foetal complications (antenatal, intrapartum, postpartum), gestational age at detection of GDM, delivery, mode of delivery, need for NICU etc. Patients with 37 weeks completed and PIH, induced with Dinoprostone gel, patient with obstetric indication for LSCS, previous LSCS and abnormal presentations were posted for LSCS. During admission for safe confinement, patient was vigorously monitored for good glycaemic control. Those patients followed up in postnatal period till 6 weeks, all underwent OGTT to know risk for development of glucose intolerance/DM.

\section{Inclusion Criteria}

1. All primigravida and multigravida.

2. Pregnant women in early second trimester.

3. With previous history of previous macrosomic baby, family history of DM/ GDM, GDM in previous pregnancy, bad obstetric history, anomalies in previous baby, polyhydramnios etc.

4. Previous LSCS.

5. Singleton pregnancies.

\section{Exclusion Criteria}

1. Patient with chronic medical illness like k/c/o DM, renal disease, lung disease, heart disease etc.

2. Patient with multifoetal gestation.

3. Patient for the first time attending to hospital in late gestation.

\section{RESULTS}

The prospective observational study was conducted in OBGY Department, KIMSDU, Karad. Total 3960 booked patients delivered in Krishna Hospital from January 2017 to May 2018, out of these 120 patients were diagnosed as GDM. Incidence of GDM in Krishna Hospital was 3\%. 20 patients were lost for follow-up, so remaining 100 patients studied further.

\begin{tabular}{|c|c|c|}
\hline Age (n= 100) & No. of Patients & \\
\hline$<25$ yrs. & 10 & $10 \%$ \\
\hline $25-30$ yrs. & 70 & $70 \%$ \\
\hline$>30$ yrs. & 20 & $20 \%$ \\
\hline \multicolumn{2}{|c|}{ Table 1. Age wise distribution of Patients } \\
\hline
\end{tabular}

$70 \%$ of the patients were in age group of $25-30 \mathrm{yrs}$.

\section{Parity Wise Distribution of Patients}

In present study, 36\% (36) patients were primigravida and $64 \%$ (64) were multigravida, out of which $9.3 \%$ (6) patients were grand multipara.

In present study, 72\% (72) patients were without any significant past history. While $2 \%(2)$ patients had a history of anomalies in previous pregnancy, 4\% (4) patients had macrosomic baby in last delivery, 6\% (6) patients had history of GDM in past pregnancy, 6\% (6) had IUD in past pregnancy and $10 \%(10)$ had previous abortions. Many of these patients had combination of significant past histories mentioned above and family history of DM.

\begin{tabular}{|c|c|c|}
\hline Gestational Age in Wks. n=100 & No. of Patients & \\
\hline$<28$ & 14 & $14 \%$ \\
\hline$>28$ & 86 & $86 \%$ \\
\hline \multicolumn{2}{|c|}{ Table 2. Gestational age at diagnosis of GDM } \\
\hline
\end{tabular}


$86 \%$ of patients were diagnosed as GDM after 28 weeks of gestation.

Out of these GDM patients, $28 \%$ (28) patients were well controlled on diet treatment. 72\% (72) patients required diet and insulin therapy for control of GDM and these 72 patients required hospitalisation for control of GDM during ANC period.

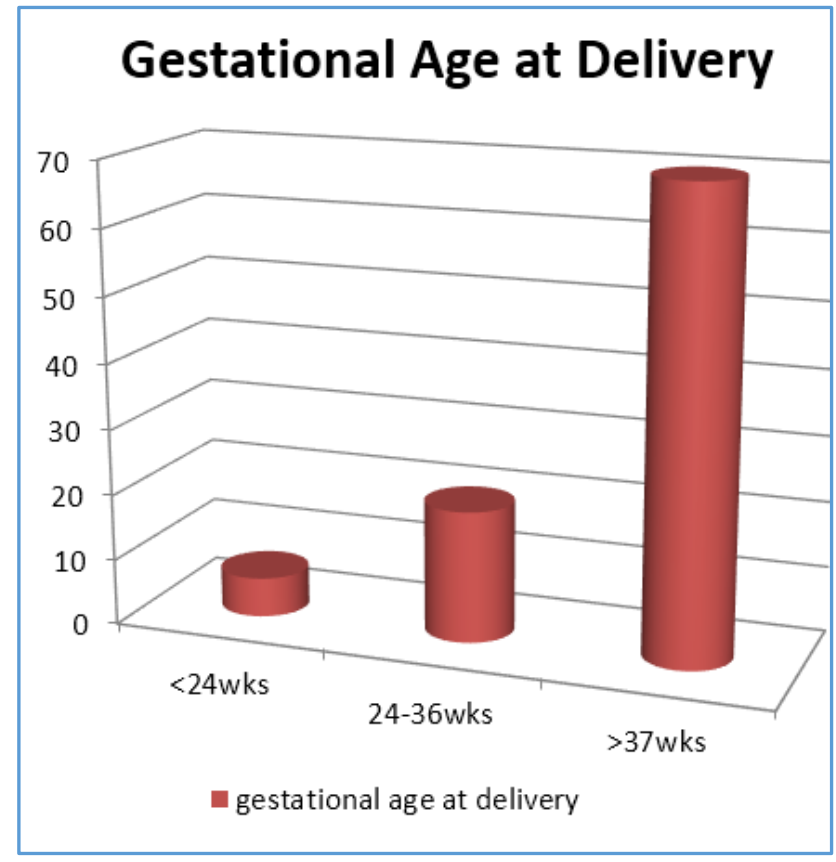

$74 \%$ patients delivered after 37 weeks of gestation, $20 \%$ had preterm deliveries. $6 \%$ patients aborted before 24 weeks of gestation.

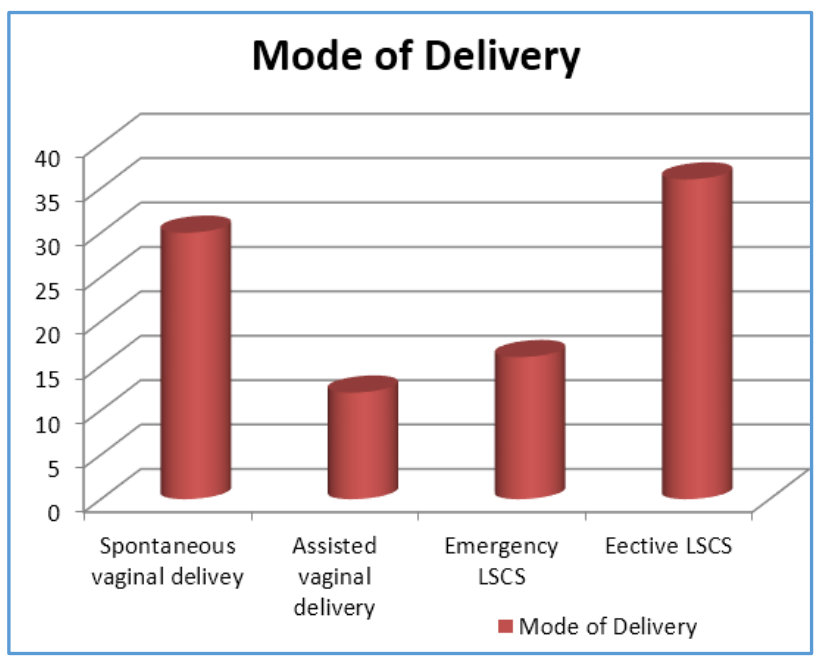

Out of 36\% elective LSCS, 14 had previous LSCS, in remaining 22 patients LSCS was done for indications such as IUGR, severe PIH, macrosomia, oligohydramnios, bad obstetric history, breech or transverse lie due to polyhydramnios etc. $16 \%$ of the patients underwent emergency LSCS for indications as foetal distress, meconium stained liquor, no progress of labour, cervical dystocia and obstructed labour.

\section{Maternal Complications during Antenatal, Intrapartum} and Postpartum Period
In present study 6 patients had abortion, 20 had preterm labour (24 weeks to 36 weeks), 10 patients had PPROM. 10 patients had Polyhydramnios, out of these one required therapeutic amniotic fluid tapping (as amniotic fluid index was 32 at gestational age 28 weeks and due to maternal discomfort), 18 patients had recurrent UTI, vaginal candidiasis or both which was treated conservatively. 16 patients had PIH, out of which 10 were on medication $\mathrm{Tb}$. Nifedipine $10 \mathrm{mg}$ or $\mathrm{Tb}$. Labetalol $100 \mathrm{mg}$ or combination of these drugs according to severity. Out of 100 GDM patients, 4 patients were known or diagnosed with hypothyroidism during present pregnancy and were on Tb. Eltroxin.

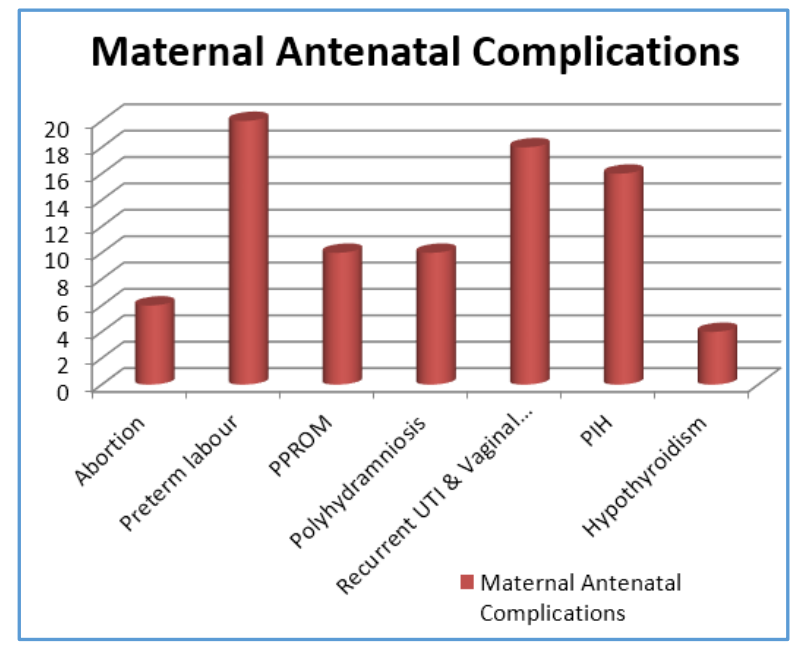

Many of these patients had combinations of complicating factors mentioned above.

In the present study 6 patients had PPH, out of which 2 had traumatic PPH due to macrosomic babies delivered to these mothers, shoulder dystocia, instrumental deliveries such as forceps or ventouse delivery and 4 had atonic PPH due to polyhydramnios, macrosomic babies etc. 6 mothers had wound sepsis and 2 mothers had wound gap. Wound sepsis was treated with antibiotics and wound gap required secondary suturing. Out of 100 patients, 62 patients followed up in postpartum period till 6 weeks. Out of which 10 patients were diagnosed with glucose intolerance in GTT and 3 had Diabetes mellitus picture on GTT.

\section{Maternal Intrapartum \& Post Partum complications}

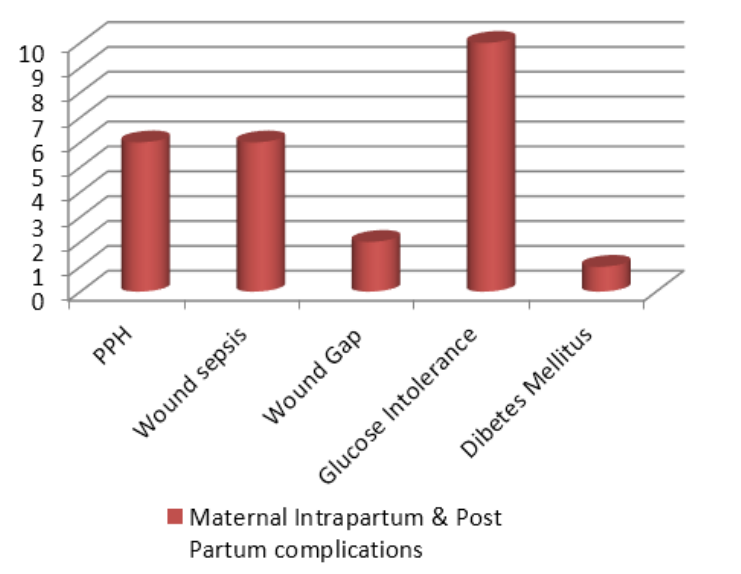




\section{Baby Outcome}

Out of 100 babies born to these mothers 6 were abortions, so these babies were excluded from this table and 94 babies born to these mothers were considered. Low birth weight babies were 8 , out of these $3(3.1 \%)$ babies were $<2 \mathrm{~kg}$, out of these 3 babies one was IUGR born at 36 weeks and 2 babies were early preterm delivery before 32 weeks and remaining $5(5.3 \%)$ babies had weight between $2-2.5 \mathrm{~kg}(3$ were preterm deliveries and 2 were full-term, but IUGR). 20 (21.27\%) babies were macrosomic > $3.5 \mathrm{~kg}$. 66 (70.21\%) babies had weight between $2.6 \mathrm{~kg}-3.5 \mathrm{~kg}$. Out of these 94 babies, 1 baby was still born $(<2 \mathrm{~kg}$ and $<32$ weeks gestation) and 2 babies were IUD (1 had weight $2.6 \mathrm{~kg}-3.5 \mathrm{~kg}$ and one had a weight $>3.5 \mathrm{~kg}$ ) and 2 babies were neonatal death (1 had weight $<2 \mathrm{~kg}$ and IUGR and 1 had weight between $2.6 \mathrm{~kg}-3.5 \mathrm{~kg}$ and this baby died due to meconium aspiration syndrome).

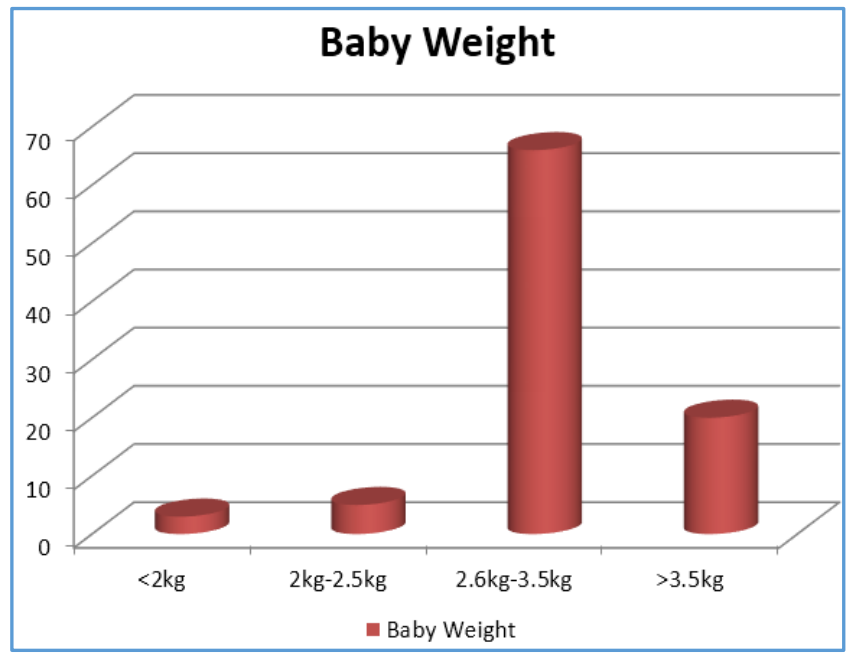

Out of 94 babies, 2 babies were IUD and 1 was stillbirth. So these three babies were excluded from present analysis regarding need for NICU admission. Out of 91 live babies, 46 (50.54\%) babies required NICU admissions for reasons such as IUGR, LBW, Birth Asphyxia, MSL, Macrosomia, Hypoglycaemia, RDS, Jaundice etc. Out of these 46 babies who required NICU admission, 2 were neonatal deaths, 1 baby was severe IUGR birth weight $<2 \mathrm{~kg}$ and the other was meconium aspiration syndrome. $45(49.4 \%)$ babies were healthy and did not require NICU admission.

\begin{tabular}{|c|c|c|c|c|}
\hline Foetal Complication & \multicolumn{4}{|c|}{ No. of Babies } \\
\hline Abortions & \multicolumn{4}{|c|}{6} \\
\hline Congenital Anomalies & \multicolumn{4}{|c|}{4} \\
\hline Macrosomia & \multicolumn{4}{|c|}{20} \\
\hline IUGR & \multicolumn{4}{|c|}{3} \\
\hline Shoulder Dystocia & \multicolumn{4}{|c|}{8} \\
\hline Hypoglycaemia & \multicolumn{4}{|c|}{14} \\
\hline RDS & \multicolumn{4}{|c|}{2} \\
\hline Jaundice & \multicolumn{4}{|c|}{10} \\
\hline Perinatal Mortality & 5 & IUD $=2$ & $\begin{array}{c}\text { Stillbirth } \\
=1\end{array}$ & $\begin{array}{l}\text { Neonatal } \\
\text { Death }=2\end{array}$ \\
\hline Shoulder Dystocia & \multicolumn{4}{|c|}{8} \\
\hline $\begin{array}{l}\text { Meconium Aspiration } \\
\text { Syndrome }\end{array}$ & \multicolumn{4}{|c|}{8} \\
\hline
\end{tabular}

Many of these babies had a combination of complications and most of live born babies required NICU admission. Out of 3 IUGR babies, 1 was neonatal death in NICU. Out of 20 macrosomic babies, 1 was neonatal death in NICU.

\section{DISCUSSION}

The present study was conducted in OBGY Department of tertiary care hospital, Krishna Hospital, KIMSDU, Karad from January 2017 to May 2018. 3960 booked pregnant women were investigated and 120 were diagnosed as GDM, 20 were lost for follow-up. So remaining 100 women diagnosed as GDM were studied till delivery. Out of these 100, 62 women were followed up till 6 weeks in postpartum period.

\begin{tabular}{|c|c|c|}
\hline Name of Study & $\begin{array}{c}\text { Incidence of } \\
\text { GDM }\end{array}$ & $\begin{array}{l}\text { No. of Patients } \\
\text { Studied }\end{array}$ \\
\hline Present study & $3 \%$ & 100 \\
\hline $\begin{array}{c}\text { Amey Dudhwadkar et } \\
\mathrm{al}^{5}\end{array}$ & $4.2 \%$ & 68 \\
\hline $\begin{array}{c}\text { Saima Yasmin Qadir et } \\
\mathrm{al}^{6}\end{array}$ & $3.5 \%$ & 100 \\
\hline Tulika et al ${ }^{7}$ & $3 \%$ & 216 \\
\hline
\end{tabular}

Incidence of GDM was $1.68 \%$ in Perveen $\mathrm{N}$ et al study, ${ }^{8}$ $2.7 \%$ in Usmani AT et al study, ${ }^{9} 3.2 \%$ in Khan KS et al study. ${ }^{10}$ $6.7 \%$ in Wahi P et al study, ${ }^{11} 7.7 \%$ in Swami SR et al study. 12 Variation in incidences of GDM in different studies were due to geographic, ethnic, racial, diet pattern variation and carbohydrate intolerance. ${ }^{13}$ The present study results are similar to Tulika et al study and Saima Yasmin Qadir et al study.

In present study, incidence of GDM in 25 - 30 years old women was $70 \%$, Amey Dudhwadkar et al study 5 it was $56 \%$ in 26 - 30 years age. Incidence of GDM was $88 \%$ in women > 25 years age in Saima Yasmin Qadir et al study. ${ }^{6}$ This prove increasing maternal age was associated with higher incidence of GDM. 14,15

In present study, 28\% patient had positive family and past history. In Amey Dudhwadkar et al study, 5 it was $20 \%$. In Nanda et al study, 16 positive family history was found in $23.9 \%$ patients.

In present study GDM was detected in 64\% multigravida, it was $72 \%$ in Amey Dudhwadkar et al study, ${ }^{5}$ it was $76 \%$ in Saima Yasmin Qadir et al study, ${ }^{6}$ while Randhawa et al ${ }^{15}$ reported $80 \%$ GDM in multiparous women. So it indicates increasing parity is a risk factor for developing GDM.

$72 \%$ patients in present study required diet and insulin therapy for good glycaemic control, while it was $15 \%$ of women with GDM who required insulin therapy in JovanovicPeterson L study 17 and $64 \%$ in Saima Yasmin Qadir et al study $^{6}$ and $40 \%$ patients were treated with insulin in Randhawa MS et al study. ${ }^{15}$ Such high number in the present study was due to illiteracy and lack of comprehension about the principles of good diabetic control.

In present study $86 \%$ GDM were diagnosed $>28$ weeks, while it was $62 \%$ in Saima Yasmin Qadir et al study. 6 In present study incidence of foetal anomaly was $4 \%$, while it was $8 \%$ in Amey Dudhwadkar et al study, $2 \%$ in Saima Yasmin Qadir et al study, ${ }^{6} 3.3 \%$ in Usmani AT et al study, ${ }^{9}$ $3.85 \%$ in Perveen $\mathrm{N}$ et al study ${ }^{8}$ and $4 \%$ in Mannan J et al study. ${ }^{18}$ 


\begin{tabular}{|c|c|c|c|c|}
\hline $\begin{array}{c}\text { Gestational } \\
\text { Age at } \\
\text { Delivery }\end{array}$ & $\begin{array}{c}\text { Present } \\
\text { Study }\end{array}$ & $\begin{array}{c}\text { Amey } \\
\text { Dudhwadkar } \\
\text { et al Study }\end{array}$ & $\begin{array}{c}\text { Saima } \\
\text { Yasmin } \\
\text { Qadir et } \\
\text { al Study }\end{array}$ & $\begin{array}{c}\text { Mahalakshmi } \\
\text { MM et al } \\
\text { Study }\end{array}$ \\
\hline$<24$ wks. & $6 \%$ & - & $2 \%$ & - \\
\hline $24-36$ wks. & $20 \%$ & $22 \%$ & $14 \%$ & $19 \%$ \\
\hline $37-40$ wks. & $74 \%$ & $78 \%$ & $84 \%$ & $77.5 \%$ \\
\hline
\end{tabular}

Table 5. Gestational Age at Delivery in different Studies

All above-mentioned study results are almost comparable to present study. Maximum no. of deliveries occurred at full term. This is because of early diagnosis and timely management and good glycaemic control.

\begin{tabular}{|c|c|c|c|}
\hline $\begin{array}{c}\text { Mode of } \\
\text { Delivery }\end{array}$ & $\begin{array}{c}\text { Present } \\
\text { Study }\end{array}$ & $\begin{array}{c}\text { Amey } \\
\text { Dudhwadkar et } \\
\text { al Study5 }\end{array}$ & $\begin{array}{c}\text { Saima Yasmin } \\
\text { Qadir et al Study6 }\end{array}$ \\
\hline $\begin{array}{c}\text { Vaginal } \\
\text { delivery }\end{array}$ & $30 \%$ & $46 \%$ & $34 \%$ \\
\hline $\begin{array}{c}\text { Assisted } \\
\text { vaginal } \\
\text { delivery }\end{array}$ & $12 \%$ & $2 \%$ & $6 \%$ \\
\hline $\begin{array}{c}\text { Elective } \\
\text { LSCS }\end{array}$ & $16 \%$ & $18 \%$ & $14 \%$ \\
\hline $\begin{array}{c}\text { Emergency } \\
\text { LSCS }\end{array}$ & $36 \%$ & $34 \%$ & $44 \%$ \\
\hline \multicolumn{4}{|c|}{ Table 6. Mode of Delivery in different Studies } \\
\hline
\end{tabular}

In present study, LSCS (both elective and emergency) rate was $52 \%$. It was almost same as studies mentioned above. This may be due to increased maternal and foetal complications related to GDM. In Yajnik CS et al study, ${ }^{20}$ the incidence of LSCS in patients with GDM was found to be $60 \%$.

\begin{tabular}{|c|c|c|c|}
\hline $\begin{array}{c}\text { Baby } \\
\text { Weight in } \\
\text { kg }\end{array}$ & $\begin{array}{c}\text { Present } \\
\text { Study }\end{array}$ & $\begin{array}{c}\text { Amey } \\
\text { Dudhwadkar et al } \\
\text { Study5 }\end{array}$ & $\begin{array}{c}\text { Saima Yasmin } \\
\text { Qadir et al } \\
\text { Study }\end{array}$ \\
\hline$<2 \mathrm{~kg}$ & $3.1 \%$ & $12 \%$ & - \\
\hline $2-2.5 \mathrm{~kg}$ & $5.3 \%$ & $8 \%$ & $6 \%$ \\
\hline $2.6-3.5 \mathrm{~kg}$ & $70.21 \%$ & $40 \%$ & $58 \%$ \\
\hline$>3.5 \mathrm{~kg}$ & $21.27 \%$ & $40 \%$ & $36 \%$ \\
\hline \multicolumn{3}{|c|}{ Table 7. Baby Weight in different Studies } \\
\hline
\end{tabular}

LBW babies $<2.5 \mathrm{~kg}$ was $8.4 \%$ in present study, which is almost correlating with Saima Yasmin Qadir et al study, ${ }^{6}$ but incidence of LBW and macrosomic babies was high in Amey Dudhwadkar et al study. 5 This variation may be due to difference in racial, nutritional glycaemic control.

\begin{tabular}{|c|c|c|c|c|}
\hline $\begin{array}{c}\text { Maternal } \\
\text { Complications }\end{array}$ & $\begin{array}{c}\text { Present } \\
\text { Study } \\
\mathrm{n}=100\end{array}$ & \begin{tabular}{|c|} 
Amey \\
Dudh \\
wadkar et \\
al Study5 \\
n=68
\end{tabular} & $\begin{array}{c}\text { Saima } \\
\text { Yasmin } \\
\text { Qadir et al } \\
\text { Study }^{6} \\
n=100\end{array}$ & $\begin{array}{c}\text { Emmanuel } \\
\text { Odar et al } \\
\text { Study21 } \\
n=90\end{array}$ \\
\hline $\begin{array}{c}\text { Spontaneous } \\
\text { abortion }\end{array}$ & 6 & - & 2 & 0 \\
\hline Preterm labour & 20 & 11 & 14 & 1 \\
\hline PPROM & 10 & - & 10 & - \\
\hline $\begin{array}{c}\text { Poly } \\
\text { hydramniosis }\end{array}$ & 10 & 10 & 18 & 2 \\
\hline $\mathrm{PIH}$ & 16 & 13 & 12 & 5 \\
\hline $\begin{array}{c}\text { Hypo } \\
\text { thyroidism }\end{array}$ & 4 & 3 & - & - \\
\hline $\begin{array}{l}\text { Recurrent UTI } \\
\text { and vaginal } \\
\text { candidiasis }\end{array}$ & 18 & 10 & 12 & 6 \\
\hline $\mathrm{PPH}$ & 6 & 3 & - & - \\
\hline
\end{tabular}

\begin{tabular}{|c|c|c|c|c|}
\hline $\begin{array}{c}\text { Neonatal } \\
\text { Compli- } \\
\text { cations }\end{array}$ & $\begin{array}{c}\text { Present } \\
\text { Study } \\
\mathbf{n}=100\end{array}$ & $\begin{array}{c}\text { Amey } \\
\text { Dudhwadkar } \\
\text { et al Study5 } \\
n=68\end{array}$ & \begin{tabular}{|c|} 
Saima \\
Yasmin \\
Qadir et \\
al Study \\
n=100
\end{tabular} & $\begin{array}{c}\text { Emmanuel } \\
\text { Odar et al } \\
\text { Study } \\
n=90\end{array}$ \\
\hline $\begin{array}{c}\text { Perinatal } \\
\text { mortality rate }\end{array}$ & $5.3 \%$ & $8 \%$ & - & $5 \%$ \\
\hline Macrosomia & $21.27 \%$ & $40 \%$ & $36 \%$ & - \\
\hline Hypoglycaemia & $15.38 \%$ & $8 \%$ & $8 \%$ & $0 \%$ \\
\hline $\begin{array}{l}\text { Meconium } \\
\text { aspiration } \\
\text { syndrome } \\
\end{array}$ & $8.5 \%$ & $4 \%$ & - & - \\
\hline $\begin{array}{l}\text { Congenital } \\
\text { anomalies }\end{array}$ & $4 \%$ & $8 \%$ & $2 \%$ & $0 \%$ \\
\hline RDS & $2.1 \%$ & $12 \%$ & $2 \%$ & - \\
\hline $\begin{array}{c}\text { Shoulder } \\
\text { dystocia }\end{array}$ & $8.5 \%$ & $4 \%$ & $6 \%$ & $23.3 \%$ \\
\hline Jaundice & $10.98 \%$ & - & $18 \%$ & - \\
\hline
\end{tabular}

In present study, 50.5\% live babies required NICU admissions for above-mentioned neonatal complications.

In present study, wound sepsis was present in $6 \%$ women and wound gap was present in $2 \%$ women. $7 \%$ patients had wound sepsis and wound gap in $1.4 \%$ in Amey Dudhwadkar et al study, ${ }^{5}$ which is almost coinciding with the present study.

Out of 100 women, 66 women followed up till 6 weeks post-partum. Out of these, 10 were diagnosed with glucose intolerance on GTT and 3 as DM. In Amey Dudhwadkar et al study, ${ }^{5}$ glucose intolerance was found in 10 and DM in 6 women on follow-up. According to a study by Mahalakshmi MM et al, ${ }^{19}$ half of the patients developed diabetes within 5 years and over $90 \%$ within 10 years after delivery.

\section{CONCLUSION}

Incidence of GDM is increasing in present era. Incidence is more as parity increases. Preventive measures for type 2 diabetes should start before birth and should be continued lifelong in children born to GDM mothers. To achieve what is needed is a small screening test for GDM in antenatal period, timely diagnosis and good glycaemic control. These preventive measures decrease neonatal morbidity and mortality and chances of developing diabetes in these children in their life. This will reduce the financial and social burden of managing complications of untreated diabetes.

\section{REFERENCES}

[1] American Diabetic Association. Diagnosis and classification of diabetes mellitus. Diabetes Care 2006;29 Suppl 1:S43-8.

[2] Dornhost A, Paterson CM, Nicholls JS, et al. High prevalence of gestational diabetes in women from ethnic minority groups. Diabet Med 1992;9(9):820-5.

[3] Carpenter MW, Coustan DR. Criteria for screening tests for gestational diabetes. AM J Obstet Gynecol 1982;144(7):768-73.

[4] Cunningham FG, Leveno KJ, Bloom SL, et al. Diabetes. Chap- 52. William's obstetrics. 22nd edn. McGraw Hill Professional 2005:1170-84.

[5] Dudhwadkar AR, Fonseca MN. Maternal and fetal outcome in gestational diabetes mellitus. Int J Reprod Contracept Obstet Gynecol 2016;5(10):3317-21. 
[6] Qadir SY, Yasmin T, Fatima I. Maternal and foetal outcome in gestational diabetes. J Ayub Med Coll Abbottabad 2012;24(3-4):17-20.

[7] Mahanta TG, Mahanta BN, Bordoloi P, et al. Maternal and foetal outcome of gestational diabetes mellitus in a rural block of Assam, India. Clinical Epidemiology and Global Health 2014;2(1):9-15.

[8] Perveen N, Saeed M. Gestational diabetes and pregnancy outcome: experience at Shaikh Zayed Hospital. Mother Child 1996;34(3):83-8.

[9] Usmani AT, Waheed N. Pregnancy complicated with diabetes: a one year experience. J Pak Institute Med Sci 1995;6(1-2):342-5.

[10] Khan KS, Rizvi JH, Qureshi RN, et al. Gestational diabetes in a developing country, experience of screening at the aga khan university medical centre, Karachi. J Pak Med Assoc 1991;41:31-3.

[11] Wahi P, Dogra V, Jandial K, et al. Prevalence of gestational diabetes mellitus (GDM) and its outcomes in Jammu region. J Assoc Physicians India 2011;59:227-30.

[12] Swami SR, Mehetre R, Shivane V, et al. Prevalence of carbohydrate intolerance of varying degrees in pregnant females in western India (Maharashtra)--a hospital-based study. J Indian Med Assoc 2008;106(11):712-4.

[13] Hadden DR. Geographic, ethnic and racial variations in the incidence of gestational diabetes mellitus. Diabetes 1985;34 Suppl 2:8-12.
[14] Negrato CA, Jovanovic L, Rafacho A, et al. Association between different levels of dysglycemia and metabolic syndrome in pregnancy. Diabetol Metab Syndr 2009;1(1):3.

[15] Randhawa MS, Moin S, Shoaib F. Diabetes mellitus during pregnancy: a study of fifty cases. Pak J Med Sci 2003;19(4):277-82.

[16] Nanda S, Savvidou M, Syngelaki A, et al. Prediction of gestational diabetes mellitus by maternal factors and biomarkers at 11 to 13 weeks. Prenat Diagn 2011;31(2):135-41.

[17] Jovanovic-Peterson L. Nutritional management of the obese pregnant women. Nutr M D 1991;17(6):1-3.

[18] Mannan J, Bhatti MT, Kamal K. Outcome of pregnancies in diabetic mothers: a descriptive study. Pak J Obstet Gynaecol 1996;9:35-40.

[19] Mahalakshmi MM, Bhavadharini B, Kumar M, et al. Clinical profile, outcomes, and progression to type 2 diabetes among Indian women with gestational diabetes mellitus seen at a diabetes center in south India. Indian J Endocrinol Metab 2014;18(3):400-6.

[20] Yajnik CS, Kale SD, Kulkarni SR, et al. High risk of diabetes and metabolic syndrome in Indian women with gestational diabetes mellitus. Diabet Med 2004;21(11):1257-9.

[21] Odar E, Wandabwa J, Kiondo P. Maternal and fetal outcome of gestational diabetes mellitus in Mulago Hospital, Uganda. Afr Health Sci 2004;4(1):9-14. 